\title{
Notch pathway inhibitor DAPT accelerates in vitro proliferation and adipogenesis in infantile hemangioma stem cells
}

\author{
$\mathrm{XING} \mathrm{XU}^{1}$, YAO WU ${ }^{1}$, HONGHONG LI ${ }^{1}$, JUAN XIE ${ }^{1}$, \\ DONGSHENG CAO ${ }^{1}$ and XUEYING HUANG ${ }^{2}$ \\ ${ }^{1}$ Department of Plastic Surgery, The Second Affiliated Hospital of Anhui Medical University; \\ ${ }^{2}$ Department of Anatomy, Anhui Medical University, Hefei, Anhui 230000, P.R. China
}

Received December 10, 2020; Accepted June 3, 2021

DOI: 10.3892/ol.2021.13115

\begin{abstract}
The Notch signaling pathway is crucial in both adipogenesis and tumor development. It serves a vital role in the development and stability of blood vessels and may be involved in the proliferative phase of infantile hemangiomas, which express various related receptors. Therefore, it was hypothesized that the Notch signaling pathway inhibitor $\mathrm{N}-[\mathrm{N}-$ (3,5-difluorophenacetyl)-L-alanyl]-S-phenylglycine t-butyl ester (DAPT), a $\gamma$-secretase inhibitor, might help accelerate the regression of infantile hemangiomas. The present in vitro study evaluated whether inhibition of the Notch signaling pathway using DAPT could alter adipogenesis in hemangioma stem cells (HemSCs) derived from infantile hemangioma (IH) specimens. A total of 20 infants (age, $\leq 6$ months) with hemangiomas who had not yet received any treatment were selected, and their discarded hemangioma tissues were obtained. HemSCs were isolated from the fresh, sterile IH specimens and treated with DAPT. Reverse transcription-quantitative PCR and western blotting were used to demonstrate the inhibition of the Notch signaling pathway by DAPT. A proliferation assay (Cell Counting Kit-8), oil red O staining, flow cytometry and a transwell assay were used to detect proliferation, adipogenesis, apoptosis and migration of HemSCs. Treatment with DAPT upregulated the expression levels of CCAAT/enhancer-binding protein $(\mathrm{C} / \mathrm{EBP}) \alpha, \mathrm{C} / \mathrm{EBP} \beta$, peroxisome proliferator-activated receptor- $\gamma$, adiponectin and insulin-like growth factor 1 , and promoted the proliferation, apoptosis, migration and lipid accumulation in HemSCs in vitro. Targeting the Notch
\end{abstract}

Correspondence to: Professor Dongsheng Cao, Department of Plastic Surgery, The Second Affiliated Hospital of Anhui Medical University, 678 Furong Road, Hefei, Anhui 230000, P.R. China E-mail: caodongsheng12345@163.com

Professor Xueying Huang, Department of Anatomy, Anhui Medical University, 81 Meishan Road, Hefei, Anhui 230000, P.R. China E-mail: 1443620806@qq.com

Key words: Notch pathway, hemangioma, N-[N(3,5-difluorophenacetyl)-L-alanyl]-S-phenylglycine t-butyl ester, $\gamma$-secretase inhibitor, adipogenesis, regression signaling pathway using DAPT may potentially accelerate the regression of infantile hemangiomas.

\section{Introduction}

Hemangioma is the most common benign tumor in infants and involves a localized angiogenic lesion (1). The lesion typically forms $\sim 2$ weeks after birth, grows for 6-10 months, and subsequently regresses, being gradually replaced by fibrous adipose tissue in the next 7-10 years (2). However, $10 \%$ of patients experience persistent hemangioma, which can lead to disfiguration, blindness and even death (3).

Promoting adipogenesis in hemangioma stem cells (HemSCs) may accelerate hemangioma regression (4). The Notch, VEGF, angiopoietin, mTOR and Bax-mediated signaling pathways have been associated with hemangioma regression (5). Compared with other options of mechanism of action, there are only a few studies on the association between the Notch signaling pathway and infantile hemangioma (IH) $(6,7)$. The Notch signaling pathway may serve a role in the occurrence and development of infantile hemangiomas $(6,7)$. However, to the best of our knowledge, the effect of Notch inhibition by $\mathrm{N}$-[N-(3,5-difluorophenacetyl)-L-alanyl]-S-phenylglycine t-butyl ester (DAPT) on IH has not been investigated. Although there may be a few scars and disfigurements, this treatment will produce fewer side effects and adverse reactions, and is more consistent with the natural progression of diseases (8). Furthermore, the expression levels of Jagged-1 and Notch-4 are increased during the proliferative phase (9), and the expression levels of Notch-1-4 and some of its ligands [delta-like 4 (DLL-4) and Jagged-1] are upregulated during the hyperplastic and regression stages (10). In addition, the Notch expression pattern can reflect vascular development from immature cells to endothelial lines (11).

The Notch signaling pathway influences cell-cell contact, proliferation, differentiation and apoptosis (12). It is highly conserved and composed of four receptors (Notch-1-4) and five ligands (Jagged-1 and -2, DLL-1, DLL-3, and DLL-4), which serve important roles in vascular development and differentiation (13-15). The expression levels of DLL-4 are increased in tumor endothelial cells (16), and act as a negative regulator of tumor angiogenesis (17). Therefore, abnormal DLL-4 expression in tumor endothelial cells can lead to arteriovenous 
malformation, blood vessel maturation and improved blood supply, which ultimately promotes tumor growth. The Notch-1 ECD fragment, comprising EGF repeats 1 to $13\left(\mathrm{~N}_{11-13}\right)$, and the Notch-1 ECD fragment, comprising EGF repeats 1 to $24\left(\mathrm{~N}_{11-24}\right)$, could control DLL-4 expression in tumor cells; however, these molecules have not been tested in clinical trials, and they are expensive and difficult to obtain (18).

The Notch signaling pathway also helps control adipogenesis in HemSCs (19). Notch gene expression influences the differentiation of bone marrow mesenchymal stem cells into adipocytes, and inhibiting Notch signaling can enhance adipogenesis in bone marrow mesenchymal stem cells (20). In addition, inhibition of Notch-3 can promote the formation of adipose-derived stem cells (21), and overexpression of the Notch intracellular domain in mice can cause fatty malnutrition (22). Activation of the Notch signaling pathway leads to two successive cleavage steps (23). The first step releases the Notch ectodomain (allowing transcription of downstream target genes), and the second step is rate-limited by the complex formed by $\gamma$-secretase and the Notch intracellular domain (24). The Notch intracellular domain is released from the cell membrane by $\gamma$-secretase and transferred to the nucleus and subsequently binds to the DNA-binding protein, hairless inhibitory factor, to regulate the expression of downstream molecules and ultimately influence differentiation, proliferation and apoptosis (25). As an inhibitor of $\gamma$-secretase, DAPT prevents the release and transcriptional activation of the Notch intracellular domain, effectively blocking the Notch signaling pathway at the Notch receptor (26).

IH treatment regimens can vary based on the location, development speed and size of the tumors (27). Based on these factors, either local or systemic treatment is selected (28). For tumors that are in the early proliferative stage without affecting the surface of the skin, milder interventions, such as laser, freezing and chemotherapy, are more effective. When tumor infiltration is deep and large and affects the daily functioning of the child, or local treatment is ineffective, systemic treatment is preferred (27). However, systemic treatment can induce adverse reactions, including hair loss, nausea, vomiting and sleep disturbances (28). In the present study, a potential therapeutic agent, DAPT, was tested, providing a novel avenue for the treatment of hemangioma.

Compared with other Notch inhibitors, $\gamma$-secretase inhibitors (e.g., DAPT) are the most popular and have been validated in numerous clinical trials $(29,30)$, while other substances have not been clinically validated. DAPT is a synthetic compound; the chemical component of DAPT is $\mathrm{N}$-[N-(3,5-Difluorophe nacetyl)-1-alanyl]-S-phenylglycine t-butyl ester; a $\gamma$-secretase inhibitor (31). Most $\gamma$-secretase inhibitors used to achieve pharmacological inhibition of Notch signaling are still in the basic or preclinical stage of development, limiting the translation of fundamental findings into clinical practice (32). Previous studies have indicated that DAPT has potential antitumor activity $(33,34)$. Therefore, the present study investigated whether the inhibition of the Notch signaling pathway using DAPT could alter adipogenesis in HemSCs derived from IH specimens.

\section{Materials and methods}

Isolation and identification of HemSCs. The study protocol was approved by the Ethics Committee of The Second
Affiliated Hospital of Anhui Medical University (approval no. YX2020-050F1; Hefei, China). Written informed consent was obtained from the guardians of the patients.

Infant hemangioma tissues were collected from 20 infants (age range, 0-6 months; median age, 4 months) with hemangioma who were yet to receive any treatment and were hospitalized between January 2018 and December 2019 at The Second Affiliated Hospital of Anhui Medical University (Hefei, China). Among the 20 infants, 9 were male patients and 11 were female patients. The inclusion criteria were as follows: i) Age $\leq 6$ months; ii) specimen confirmed as hemangioma by clinicians and pathologist and was in the proliferative phase (35)]; and iii) written informed consent was obtained from the legal guardians of the patients. Hemangioma tissues were surgically resected and stored immediately in DMEM (Cytiva) with high glucose, $10 \%$ FBS (Biological Industries) and 1\% penicillin-streptomycin (Beyotime Institute of Biotechnology) at $4^{\circ} \mathrm{C}$. Fat and skin tissues were removed, and the specimens were washed three times using PBS (Beyotime Institute of Biotechnology) before being cut into 0.1-mm slices. The slices were digested at $37^{\circ} \mathrm{C}$ for $2 \mathrm{~h}$ in water and $0.2 \%$ Collagen $\mathrm{R}$ solution (SERVA Electrophoresis $\mathrm{GmbH}$ ). The sample was strained twice using a 100- $\mu \mathrm{m}$ filter, and CD133-positive HemSCs were collected from the resulting suspension using the magnetic bead technique (36). The purified HemSCs were cultured at $37^{\circ} \mathrm{C}$ with $5 \% \mathrm{CO}_{2}$ using endothelial cell medium (ECM; ScienCell Research Laboratories, Inc.) supplemented with 10\% FBS and $1 \%$ penicillin-streptomycin (PS). The presence of CD133 in the cells was confirmed by a BD LSR II flow cytometer (Becton, Dickinson and Company) using TruCountTM tubes (BD Biosciences). The absolute count of the cell population was obtained using FlowJo Analysis Software V10 (Tree Star, Inc.).

DAPT treatment and proliferation assay. For the proliferation assay, HemSCs were seeded into 96-well plates (Corning, Inc.) at a density of $1.0 \times 10^{3}$ cells/well. After $24 \mathrm{~h}$ of serum starvation, DAPT (Beyotime Institute of Biotechnology) was added at concentrations of $0,10,20,40$ and $60 \mu \mathrm{M}$, and the cells were cultured at $37^{\circ} \mathrm{C}$ for $72 \mathrm{~h}$. Subsequently, Cell Counting Kit-8 (CCK-8) reagent (Dojindo Molecular Technologies, Inc.) was added to the culture and incubated for $4 \mathrm{~h}$. Then, absorbance was measured at $490 \mathrm{~nm}$ using a microplate reader (ELx800; BioTek Instruments, Inc.). Another set of cells were then similarly recultured and treated with the optimumDAPT concentration that resulted in the highest absorbance in the previous culture for $0,24,48,72$ and $96 \mathrm{~h}$, followed by the CCK-8 assay, as aforementioned. Subsequently, HemSCs were seeded at a density of $1 \times 10^{6}$ cells $/ \mathrm{ml}$ into 6 -well plates (Corning, Inc.) and cultured until they reached 50-60\% confluence. The HemSCs were then starved in a serum-free medium for $24 \mathrm{~h}$, and treated with DAPT at concentrations of 2.5, 5, 10,20 and $40 \mu \mathrm{M}$, which were prepared from a stock solution in DMSO (Beyotime Institute of Biotechnology). The final concentration of DMSO in the culture medium was $<0.25 \%$. After $24 \mathrm{~h}$ of DAPT treatment in a $37^{\circ} \mathrm{C}$ incubator with $5 \% \mathrm{CO}_{2}$, the medium was changed to a DAPT-free medium. The optimal concentration $(40 \mu \mathrm{M})$ of DAPT that resulted in the lowest measurable expression of Notch-1 and -3 and the strongest cell viability was used for subsequent experiments. The medium was changed every $24 \mathrm{~h}$. 
Table I. Primer sequences used for reverse transcriptionquantitative PCR.

\begin{tabular}{ll}
\hline Gene & \multicolumn{1}{c}{ Sequence (5'-3') } \\
\hline Notch-1 & F: AACAGCGAGGAAGAGGAGGA \\
& R: GCATCAGAGCGTGAGTAGCG \\
Notch-3 & F: ATCGGCTCGGTAGTAATG \\
& R: ACCTCCCAGGTAGTCA \\
$\beta$-actin & F: CTGGAACGGTGAAGGTGACA \\
& R: AAGGGACTTCCTGTAACAATGCA
\end{tabular}

F, forward; R, reverse.

Adipogenic differentiation. DAPT $(40 \mu \mathrm{M})$-treated HemSCs were evaluated by seeding $5.0 \times 10^{4}$ cells in 6 -well plates at $37^{\circ} \mathrm{C}$ for $24 \mathrm{~h}$. The standard medium (ECM plus $10 \% \mathrm{FBS}$ and $1 \%$ PS) was replaced with an adipogenic differentiation medium (GUXMX-90031; Cyagen Biosciences, Inc.). The cells were cultured in the adipogenic differentiation medium in a $37^{\circ} \mathrm{C}$ incubator with $5 \% \mathrm{CO}_{2}$ for 14 days, and the medium was replaced every $72 \mathrm{~h}$.

Reverse transcription-quantitative PCR (RT-qPCR). Total RNA was extracted from HemSCs using TRIzol ${ }^{\circledR}$ reagent (Invitrogen; Thermo Fisher Scientific, Inc.), and mRNA was reverse transcribed into cDNA using the PrimeScript ${ }^{\mathrm{TM}}$ RT kit (Takara Biotechnology Co., Ltd.), all steps were performed on ice. Reverse transcription was conducted at $37^{\circ} \mathrm{C}$ for $15 \mathrm{~min}$, followed by $85^{\circ} \mathrm{C}$ for $5 \mathrm{sec}$ and $4^{\circ} \mathrm{C}$ for $10 \mathrm{~min}$ for heat inactivation. The expression levels of Notch-1 and Notch-3 at different DAPT concentrations were measured, and then the expression levels of proliferator-activated receptor- $\gamma(\operatorname{PPAR} \gamma)$, CCAAT/enhancer-binding protein (C/EBP) $\alpha, \mathrm{C} / \mathrm{EBP} \beta$, adiponectin and insulin-like growth factor 1 (IGF-1) at the same concentration were measured after the optimal concentration was determined. The expression levels of Notch-1, Notch-3, peroxisome PPAR $\gamma, \mathrm{C} / \mathrm{EBP} \alpha, \mathrm{C} / \mathrm{EBP} \beta$, adiponectin and IGF-1 were quantified using $\beta$-actin as an endogenous control. The CFX Connect Real-Time System (Bio-Rad Laboratories, Inc.) was used for RT-qPCR according to the manufacturer's protocol, as follows: Preheating at $95^{\circ} \mathrm{C}$ for $10 \mathrm{~min}$, followed by 40 cycles of $95^{\circ} \mathrm{C}$ for $15 \mathrm{sec}$ and $60^{\circ} \mathrm{C}$ for $1 \mathrm{~min}$, extension at $72^{\circ} \mathrm{C}$ for $35 \mathrm{sec}$, and $4^{\circ} \mathrm{C}$ for preservation. The results were normalized to $\beta$-actin expression levels, and the samples were analyzed in triplicate (37). Analysis of relative gene expression data was obtained by RT-qPCR using the $2^{-\Delta \Delta C q}$ method (38). The primer sequences are shown in Table I (Notch-1 and -3) and Table II (PPAR $\gamma, \mathrm{C} / \mathrm{EBP} \alpha, \mathrm{C} / \mathrm{EBP} \beta$, adiponectin and IGF-1). Each reaction was performed in duplicate in a total volume of $20 \mu \mathrm{l}$, containing1 $\mu \mathrm{l}$ cDNA, $10 \mu \mathrm{l} \mathrm{SYBR}{ }^{\circledR}$ Premix Ex Taq II (Takara Biotechnology Co., Ltd.), $1 \mu 1$ of each primer pair and $7 \mu \mathrm{l}$ DNase/RNase-free water (Beijing Solarbio Science \& Technology Co., Ltd.). The relative mRNA expression levels were measured using the $2^{-\Delta \Delta \mathrm{Cq}}$ method (37) in triplicate.

Western blot analysis. HemSCs were cultured at $37^{\circ} \mathrm{C}$ for $24 \mathrm{~h}$ after $24 \mathrm{~h}$ of treatment with DAPT at varying concentrations
Table II. Primer sequences used for reverse transcriptionquantitative PCR.

\begin{tabular}{ll}
\hline Gene & \multicolumn{1}{c}{ Sequence (5'-3') } \\
\hline PPAR $\gamma$ & F: CCATCCGCATCTTTCA \\
& R: GAGTTACTTGGTCGTTC \\
C/EBP $\alpha$ & F: GGTGGACAAGAACAGCAACGAGT \\
& R: CCAGCACCTTCTGCTGCGTCT \\
C/EBP $\beta$ & F: GGGCAAGAACTGCAAGAAGCC \\
& R: GCCTGGTAGCCGAGGTAAGC \\
Adiponectin & F: AGGGAGACATCGGTGAAA \\
& R: AAGTAGTACAGCCCAGGAAT \\
IGF-1 & F: TATTTCAACAAGCCCACAG \\
& R: ATACATCTCCAGCCTCCTTA \\
$\beta$-actin & F: GGCACCCAGCACAATGAA \\
& R: TAGAAGCATTTGCGGTGG
\end{tabular}

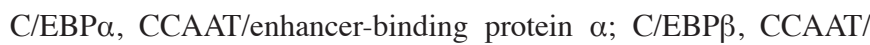
enhancer-binding protein $\beta ; \mathrm{F}$, forward; IGF-1, insulin-like growth factor 1 ; PPAR $-\gamma$, peroxisome proliferator-activated receptor- $\gamma$; $\mathrm{R}$, reverse.

$(2.5,5,10,20$ and $40 \mu \mathrm{M})$ at $37^{\circ} \mathrm{C}$ and then homogenized in RIPA buffer (Beyotime Institute of Biotechnology) containing protease inhibitors (Pierce; Thermo Fisher Scientific, Inc.). The lysate was centrifuged at $4^{\circ} \mathrm{C}$ in $16,099 \mathrm{x}$ g for $30 \mathrm{~min}$ to remove cell fragments, and the protein-containing supernatant was boiled in a sample protein buffer for $10 \mathrm{~min}$. A Bradford Protein Assay kit (Beyotime Institute of Biotechnology) was utilized to determine the protein concentrations. The protein extracts $(73 \mu \mathrm{g} /$ lane) were subjected to sodium dodecyl sulfate polyacrylamide gel electrophoresis (Wuhan Servicebio Technology Co., Ltd.) on $10 \%$ polyacrylamide gels, and separated proteins were transferred to a polyvinylidene fluoride membrane (Cell Signaling Technology, Inc.). The membranes were blocked with $0.24 \%$ Tween- 20 containing 5\% non-fat milk for $2 \mathrm{~h}$ at room temperature, and incubated with primary antibodies targeting $\beta$-actin (dilution, 1:1,000; cat. no. AF7018; Affinity Biosciences), Notch-1 (dilution, 1:500; cat. no. WL01991; Wanleibio Co., Ltd.) and Notch-3 (dilution, 1:500; cat. no. WL02051; Wanleibio Co., Ltd.) at $4^{\circ} \mathrm{C}$ overnight. The optimal concentration of DAPT was selected based on the lowest expression levels of Notch-1 and -3, as measured by RT-qPCR and western blotting. Additional cultures were prepared and protein samples were collected to evaluate the effects of DAPT treatment on the expression levels of $\beta$-actin (dilution, 1:500; cat. no. 3700; Cell Signaling Technology, Inc.), PPAR $\gamma$ (dilution, 1:500; cat. no. BS-0530R-2; BIOSS), C/EBP $\alpha$ (dilution, 1:1,000; cat. no. BS-1630R; BIOSS), C/EBP $\beta$ (dilution, 1:1,000; cat. no. BS-1396R; BIOSS), adiponectin (dilution, 1:1,000; cat. no. BS-0471R; BIOSS) and IGF-1 (dilution, 1:1,000; cat. no. BS-0014R; BIOSS). Membranes were incubated with horseradish peroxidase-conjugated secondary antibody (cat. no.ZB2301; OriGene Technologies, Inc.) mixed with TBS with $0.24 \%$ Tween-20 at a ratio of $1: 10,000$ for $1 \mathrm{~h}$ at $37^{\circ} \mathrm{C}$. The signal was detected using enhanced chemiluminescence 
reagents (Beyotime Institute of Biotechnology), and protein expression was semi-quantified based on grayscale analysis using ImageJ software (version 1.51s; National Institutes of Health).

Oil red $O$ staining. After 14 days of adipogenic differentiation, the cells were washed with PBS and fixed in $4 \%$ paraformaldehyde at $37^{\circ} \mathrm{C}$ for $40 \mathrm{~min}$. After the third wash, cells were stained for $10 \mathrm{~min}$ using a 40:60 mixture of water and a solution containing oil red O (100 ml isopropyl alcohol and $0.5 \mathrm{~g}$ oil red O; Sigma-Aldrich; Merck KGaA) and filtered at $37^{\circ} \mathrm{C}$ for $30 \mathrm{~min}$. The cells were observed and images were captured using an inverted light microscope (Nikon Corporation), and droplets were quantified using ImageJ software. The Oil Red O-stained cells were quantified using ImageJ software. Data are presented as the average percentage of the maximum signal $\%$.

Apoptosis assay. To evaluate apoptosis, HemSCs were seeded at a density of $1.0 \times 10^{6}$ cells/well into 6 -well plates (Corning, Inc.) and treated with $40 \mu \mathrm{M}$ DAPT at $37^{\circ} \mathrm{C}$ for $24 \mathrm{~h}$, followed by staining with fluorescein isothiocyanate-bound annexin $\mathrm{V}$ and propidium iodide (apoptosis detection kit; Beyotime Institute of Biotechnology). Cells were harvested and counted in a volume of $100 \mu \mathrm{l}$ on a BD LSR II flow cytometer (Becton, Dickinson and Company) using TruCountTM tubes (BD Biosciences). Flow cytometry was used to determine the proportion of apoptotic cells. ModFit L T (4.0; Verity Software House, Inc.) was used in quantitative analysis of apoptosis. Additional cultures were prepared, and the cells were cultured in the adipogenic differentiation medium for 14 days after DAPT treatment. Subsequently, the cells were collected, and apoptosis was examined again by flow cytometry.

Transwell assay. Migration was evaluated at $37^{\circ} \mathrm{C}$ using 24-well Transwell inserts with ECM $(600 \mu \mathrm{l})$ containing $30 \% \mathrm{FBS}$ in the lower chambers. After $24 \mathrm{~h}$ of treatment with DAPT, $2 \times 10^{4}$ HemSCs were added to $200 \mu \mathrm{l}$ DMEM in the upper chambers at room temperature. After another $24 \mathrm{~h}$ of incubation at $37^{\circ} \mathrm{C}$, the cells in the bottom chambers were washed twice with PBS, fixed with $4 \%$ paraformaldehyde for $30 \mathrm{~min}$ and stained with a $0.1 \%$ crystal violet solution for $10 \mathrm{~min}$ at room temperature. After three washes with PBS, the cells were observed under a light microscope (magnification, x100) and the migratory cells were quantified using ImageJ software. Data are presented as the average percentage of the maximum signal $\%$.

Statistical analysis. Data are presented as the mean \pm standard deviation ( $\mathrm{n}=3$ for each experiment) and were analyzed using IBM SPSS software (version 23; IBM Corp.). An unpaired Student's t-test was used to assess the differences between two groups, for multiple groups, one-way analysis of variance followed by Bonferroni statistical tests was used to assess the mean values, $\mathrm{P}<0.05$ was considered to indicate a statistically significant difference.

\section{Results}

Optimal concentration of DAPT for inhibition of the Notch signaling pathway. HemSCs were identified by flow cytometry.
A

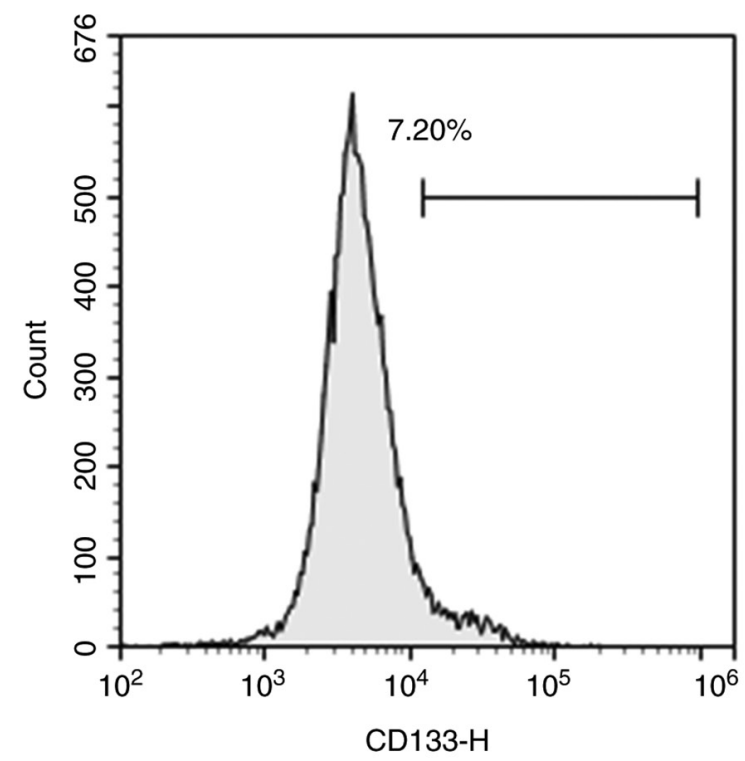

B

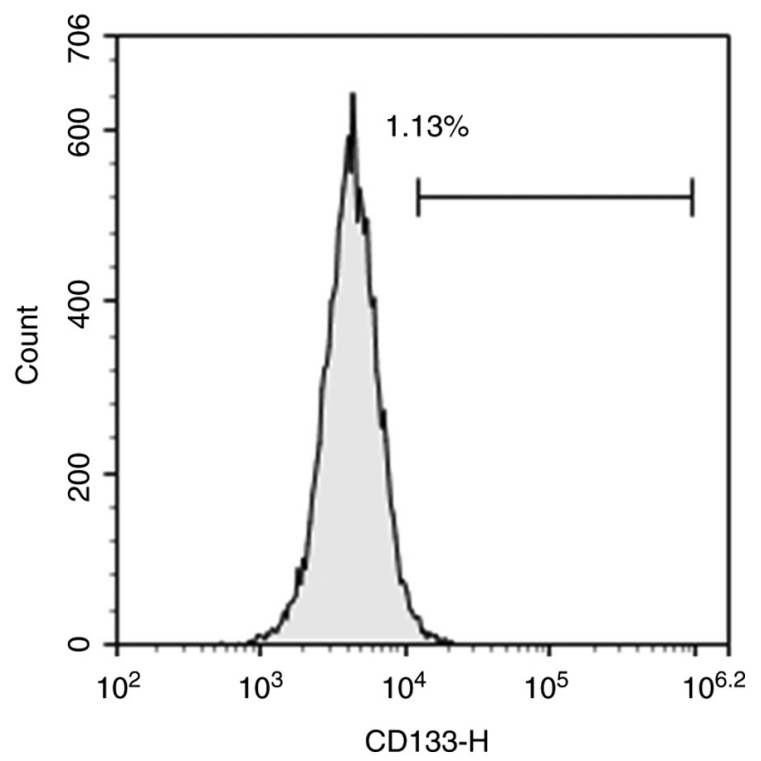

Figure 1. After magnetic bead sorting, (A) the CD133-positive rate of the first generation of hemangioma stem cells was $7.20 \%$, and (B) that of the third generation was $1.13 \%$.

After magnetic bead sorting, the CD133 positivity rate of the first generation of HemSCs was $7.20 \%$ (Fig. 1A) and that of the third generation was $1.13 \%$ (Fig. 1B). This demonstrated that the proportion of CD133-positive cells decreased with the increase of passage number. The results of RT-qPCR (Fig. 2A and B) and western blotting (Fig. 2C-E) demonstrated that treatment with DAPT influenced the expression levels of Notch-1 and -3 . When the DAPT concentration was $40 \mu \mathrm{M}$, the expression levels of Notch-1 and -3 were the lowest, which was the optimal concentration of DAPT (data not shown).

Effects of DAPT on HemSCs. Adipogenic differentiation for 14 days followed by DAPT treatment increased adiponectin (Fig. 3A), C/EBP $\alpha$ (Fig. 3B), C/EBP $\beta$ (Fig. 3C) and PPAR $\gamma$ (Fig. 3D) mRNA and protein (Fig. 3F) expression compared with the DMSO and the blank control groups. DAPT-treated 

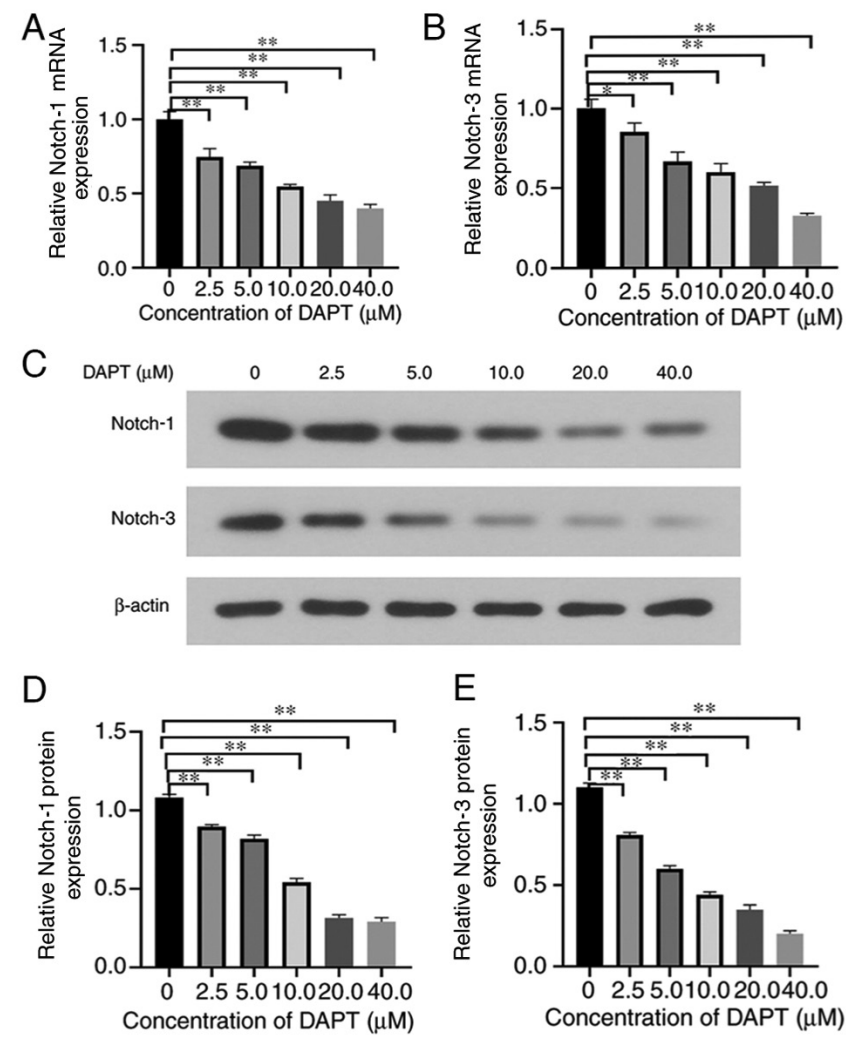

Figure 2. Expression levels of Notch-1 and Notch-3 in hemangioma stem cells, which were treated with six concentrations of DAPT ( $0,2.5,5,10,20$ and $40 \mu \mathrm{M})$. Expression levels of (A) Notch-1 and (B) Notch-3 mRNA. In addition, the protein expression levels of Notch-1 and Notch-3 were evaluated using (C) western blotting and semi-quantified using $\beta$-actin as the loading control. The band densities of (D) Notch-1 and (E) Notch-3 were analyzed using ImageJ software ${ }^{*} \mathrm{P}<0.05,{ }^{* *} \mathrm{P}<0.01$ (n=3). DAPT, N-[N-(3,5-difluorophenacetyl)-L-alanyl]-S-phenylglycine t-butyl ester.

cells exhibited higher expression levels of adiponectin (Fig. 3G), C/EBP $\alpha$ (Fig. 3H), C/EBP $\beta$ (Fig. 3I), and PPAR $\gamma$ (Fig. 3J) than those in the control groups (CON, ADIP and ADIP+DMSO). DAPT-treated adipogenic cells exhibited the highest expression levels of IGF-1, which were significantly higher than the other three control groups (Fig. 3E and K), whereas treatment with DMSO alone did not significantly influence the expression levels of IGF-1 compared with those of the ADIP group.

It was also observed that treatment with DAPT increased the number and size of adipocytes based on oil red $\mathrm{O}$ staining of HemSCs after 14 days of adipogenic differentiation. The size of Oil Red O-stained cells was quantified using Image J software (Fig. 4A and B). DAPT-treated adipogenic cells had the highest number and largest size of lipid droplets, whereas treatment with DMSO alone did not appear to influence those parameters. DAPT promoted the migration of HemSCs (Fig. 4C and D) compared with the DMSO and control groups; however, no significant difference was observed between the control and DMSO groups. Apoptotic cells were detected using flow cytometry, which revealed that treatment with DAPT promoted apoptosis in HemSCs compared with that of the DMSO and control groups (Fig. 5A).

The inhibition of Notch signaling was proportional to the concentrations of DAPT used $(2.5-40 \mu \mathrm{M})$. DAPT at $40 \mu \mathrm{M}$ induced the greatest proliferation among all groups in the cell proliferation assay (0-60 $\mu \mathrm{M}$; Fig. 5B). Therefore, the greatest inhibitory effect and proliferation were induced when the concentration of DAPT was $40 \mu \mathrm{M}$. Therefore, all other experiments were performed using a DAPT concentration of $40 \mu \mathrm{M}$. The proportions of apoptotic cells were not significantly different between the groups cultured in adipogenic medium with DMSO and those cultured in adipogenic medium without DMSO (Fig. 5A). However, the proportion of apoptotic cells was the highest in the group cultured in DAPT-containing adipogenic medium, and the proportion of apoptotic cells was the lowest in the group cultured in no-treatment medium. The three adipogenesis groups (ADIP,ADIP+DMSO and ADIP+DAPT) also had higher proportions of apoptotic cells, and there was no difference observed between the control and DMSO groups (Fig. 5A). Based on the absorbance values at $490 \mathrm{~nm}$ in the CCK-8 assay, DAPT stimulated the proliferation of HemSCs (days 1-5) when compared with the control group. The highest absorbance value was observed in the DAPT-treated group, and the proliferation of DAPT-treated HemSCs (days 3-5) was particularly promoted compared with that of the untreated group (Fig. 5C). Furthermore, there was no significant difference in proliferation between the DMSO and control groups.

\section{Discussion}

The Notch signaling pathway is essential in regulating various biological functions, tumor growth (39), vascular endothelial cell proliferation and adipogenesis $(10,40)$. Previous studies have demonstrated that inhibition of the Notch signaling pathway can promote adipogenesis in cells $(41,42)$. DAPT inhibits Notch receptor enzymatic hydrolysis, intracellular domain release and 
A

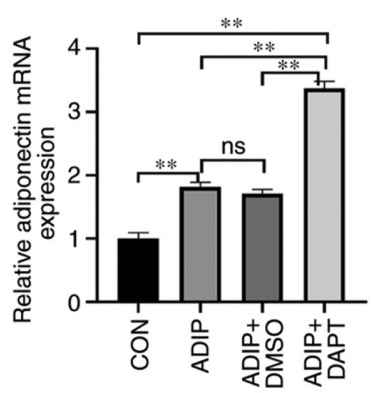

D
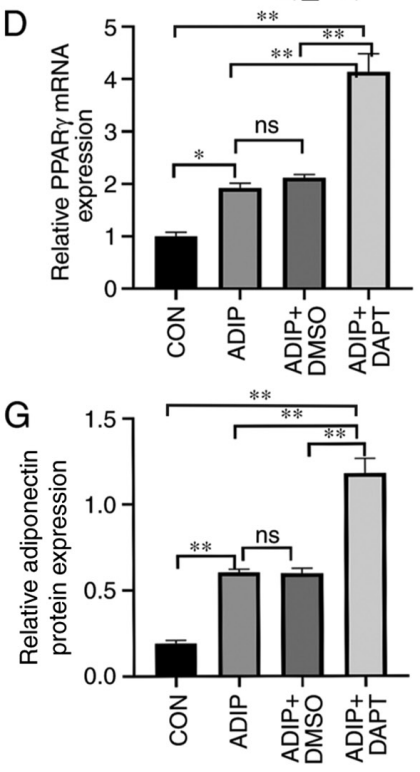

I

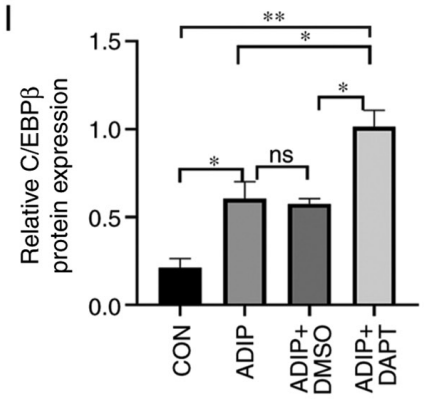

B

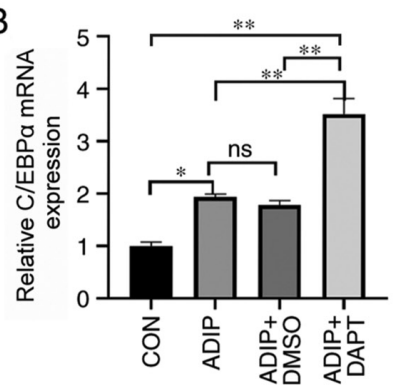

E

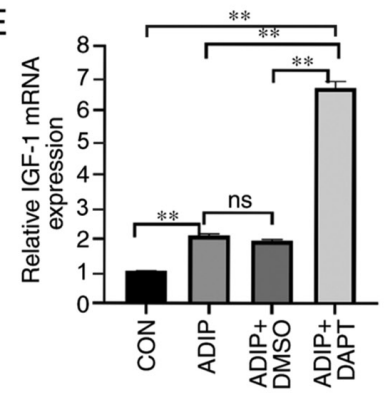

$\mathrm{H}$

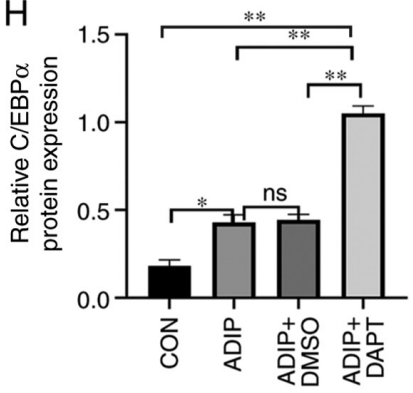

$J$

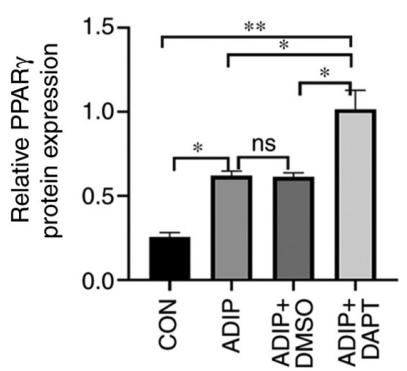

C
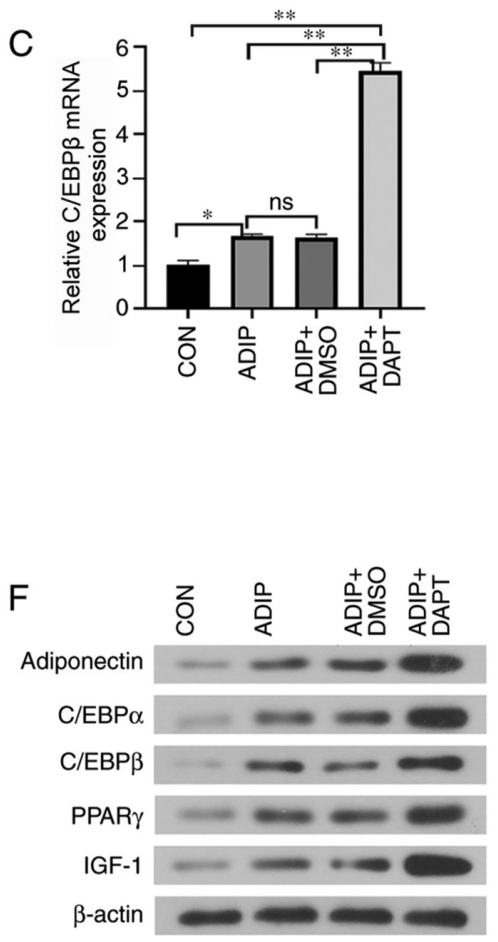

$\mathrm{K}$

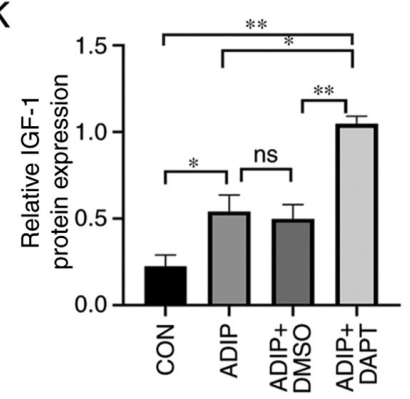

Figure 3. Exposure to DAPT promotes adipogenesis and hemangioma stem cell expression of adiponectin, C/EBP $\alpha, \mathrm{C} / \mathrm{EBP} \beta$ and PPAR $\gamma$. Expression levels of (A) adiponectin, (B) $\mathrm{C} / \mathrm{EBP} \alpha$, (C) $\mathrm{C} / \mathrm{EBP} \beta$, (D) PPAR $\gamma$ and (E) IGF-1. In addition, expression was evaluated using (F) western blotting and semi-quantified using $\beta$-actin as the loading control. The band densities of $(\mathrm{G})$ adiponectin, (H) C/EBP $\alpha$, (I) C/EBP $\beta$, (J) PPAR $\gamma$ and (K) IGF-1 were analyzed using ImageJ software. $\mathrm{n}=3$. $\mathrm{ns}, \mathrm{P}>0.05,{ }^{*} \mathrm{P}<0.05,{ }^{* *} \mathrm{P}<0.01(\mathrm{n}=3)$. ADIP, adipogenic medium; ADIP+DAPT, adipogenic medium containing DAPT; ADIP+DMSO, adipogenic medium containing DMSO; C/EBP $\alpha$, CCAAT/enhancer-binding protein $\alpha$; C/EBP $\beta$, CCAAT/enhancer-binding protein $\beta$; CON, control; DAPT, $\mathrm{N}$-[N-(3,5-difluorophenacetyl)-L-alanyl]-S-phenylglycine t-butyl ester; IGF-1, insulin-like growth factor 1; ns, not significant; PPAR $\gamma$, peroxisome proliferator-activated receptor- $\gamma$.

transcriptional activation by inhibiting $\gamma$-secretase activity (43). It effectively blocks the signal from Notch receptor and thus inhibits the activation of the Notch signaling pathway (30). DAPT has also been documented to have little effect on other cellular signaling pathways (44). Previously, $\gamma$-secretase inhibitors were mainly used to treat Alzheimer's disease (45); however, they have also been demonstrated to inhibit lung, breast, colorectal and pancreatic cancer (46-49). However, deletion of Notch functional mutations in hepatocellular carcinoma and melanoma has established its role as a tumor suppressor (50). The activation of the Notch signaling pathway inhibits adipogenesis through autophagy activation and the
PTEN-PI3K/AKT/mTOR signaling pathway (20). The Notch signaling pathway inhibitors suppress this process and promote adipocyte differentiation (19-20,51). It was hypothesized that the inhibition of the Notch signaling pathway might influence the proliferation of HemSCs and this hypothesis was examined by measuring cell proliferation after treatment with five concentrations of DAPT $(0,10,20,40$ and $60 \mu \mathrm{M})$. In the range of $0-40 \mu \mathrm{M}, \mathrm{HemSCs}$ were in the proliferative state; however, when the concentration of DAPT rose to $60 \mu \mathrm{M}$, the proliferation decreased. The greatest reduction in Notch-1 and -3 mRNA and protein expression was observed at a DAPT concentration of $40 \mu \mathrm{M}$; however, concentration-dependent inhibition was 
A

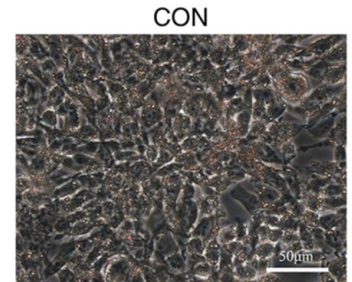

ADIP+DMSO

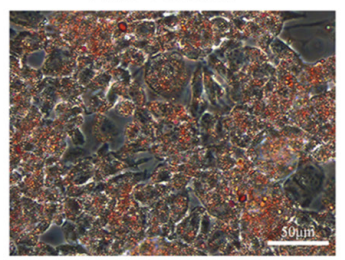

C

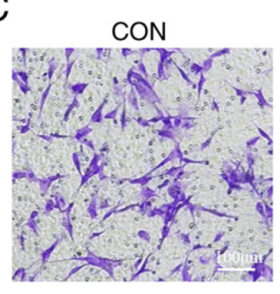

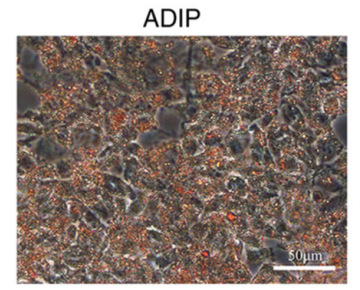

ADIP+DAPT

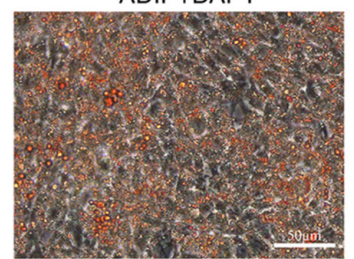

\section{B}

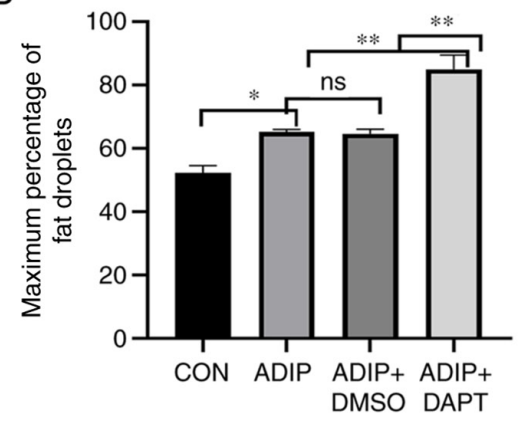

D

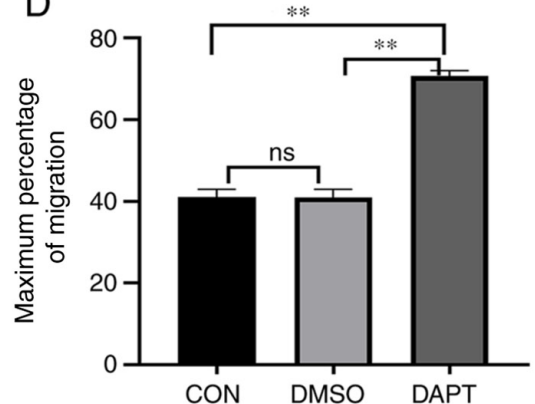

Figure 4. Differentiation and migration of HemSCs were improved by DAPT exposure. (A) Adipogenic differentiation of HemSCs. Magnification, x400. (B) Droplets were quantified using ImageJ software. The Oil Red O-stained cells were quantified using ImageJ software. Data are presented as the average percentage of the maximum signal \%. (C) Migration of HemSCs and (D) number of migrated cells at a magnification of x100. The migratory cells were quantified using Image $\mathrm{J}$ software. Data are presented as the average percentage of the maximum signal \%. Exposure to DAPT was associated with an increase in adipocyte number and size. $\mathrm{n}=3$. ns, $\mathrm{P}>0.05 ;{ }^{*} \mathrm{P}<0.05 ;{ }^{* *} \mathrm{P}<0.01 \quad(\mathrm{n}=3)$. CON, control; DAPT, N-[N-(3,5-difluorophenacetyl)-L-alanyl]-S-phenylgl ycine t-butyl ester; ADIP, adipogenic medium; ADIP+DAPT, adipogenic medium containing DAPT; ADIP+DMSO, adipogenic medium containing DMSO; HemSCs, hemangioma stem cells; ns, not significant.

observed in the range of $2.5-40 \mu \mathrm{M}$, suggesting that there is a dose-response relationship.

The regression of IH occurrs due to simultaneous increase in apoptosis and adipogenesis (52). The Bcl-2 family members, Bcl-2, Bcl-x (53), giant seaperch iridovirus serine/threonine kinase (54) and voltage-dependent anion channel 2 (55), are also mainly associated with apoptosis through a Bax-mediated mechanism. The Notch signaling pathway serves an important role in angiogenesis and tumorigenesis, and only a few studies have investigated the role of Notch signaling in tumor regression $(56,57)$. The present data indicated that DAPT inhibited Notch signaling and could accelerate adipogenesis and apoptosis in IH. Adipogenesis is regulated by a variety of factors, including $\mathrm{C} / \mathrm{EBP} \alpha, \mathrm{C} / \mathrm{EBP} \beta, \mathrm{PPAR} \gamma$ and adiponectin (58). The $\mathrm{C} / \mathrm{EBP}$ molecules serve different roles in regulating adipocyte differentiation (59): In pre-adipocytes, $\mathrm{C} / \mathrm{EBP} \beta$ accelerates the induction of $\mathrm{C} / \mathrm{EBP} \alpha$, which is an important part of the genetic cascade leading to adipogenesis (60). $\mathrm{C} / \mathrm{EBP} \alpha$ is an adipogenic transcription factor, which cannot independently induce adipogenesis and requires the co-activity of PPAR $\gamma$, which is a transcription factor that can independently induce adipogenic differentiation (61). Additionally, adiponectin promotes pre-adipocyte differentiation via the PPAR $\gamma$ signaling pathway (62). Cell proliferation, differentiation and apoptosis depend on activation of the IGF-1 signaling pathway (63). IGF-1 serves an important role in fat formation in HemSCs arising from $\mathrm{IH}$ and may be of interest for the treatment of $\mathrm{IH}$ (64).
However, at present, the present fundamental research is only at the cell level and has not yet been certified in clinical trials. This will be investigated in subsequent studies.

The IGF-1 polypeptide has multiple binding sites and can help regulate tumor development, growth and metastasis by inhibiting apoptosis, advancing the cell cycle and regulating angiogenesis (65). Furthermore, our previous study revealed that IGF-1 regulates adipogenesis and proliferation of HemSCs, which may involve the IGF-1 receptor and PI3K signaling pathways (66).

Given the inter-relatedness of the aforementioned processes, it was hypothesized that DAPT may accelerate IH regression via the Notch and IGF-1 signaling pathways, and this hypothesis was examined in the present in vitro study.

A previous study has indicated that linsitinib (OSI-906, an IGF-1 receptor inhibitor) can reduce the expression of $\mathrm{C} / \mathrm{EBP} \alpha, \mathrm{C} / \mathrm{EBP} \beta, \mathrm{PPAR} \gamma$ and adiponectin (67). In the present study, treatment with DAPT increased the expression levels of IGF-1 in HemSCs. It was hypothesized that the IGF-1 signaling pathway also influences adipogenesis in infantile hemangioma. Therefore, treatment with DAPT may be useful for driving the regression of IH by influencing IGF-1 signaling.

One of the limitations of the present study was that the upper concentration limit for the inhibitory effects of DAPT was not established. In addition, only in vitro experiments were performed to characterize the effects of treatment with DAPT 
A
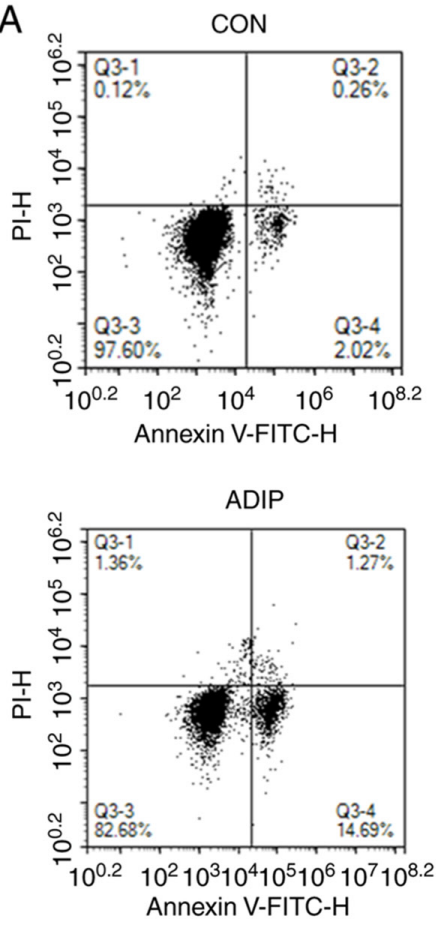

B

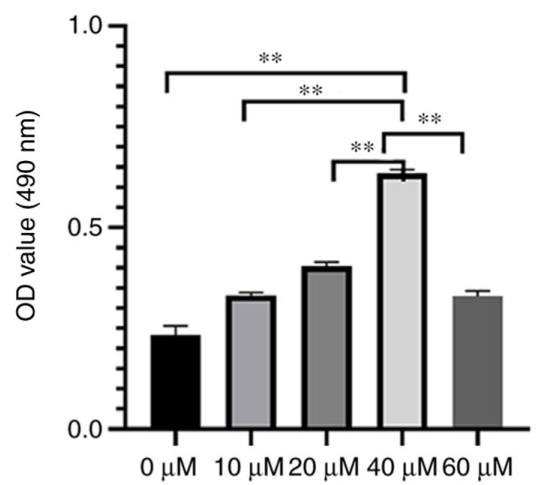

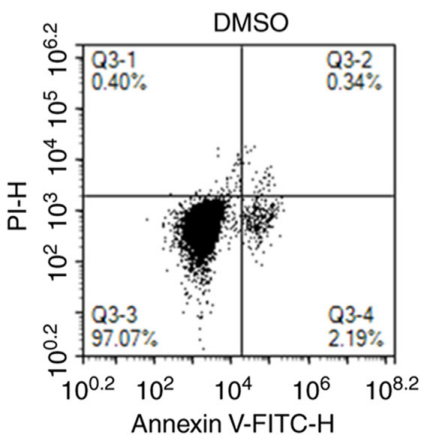
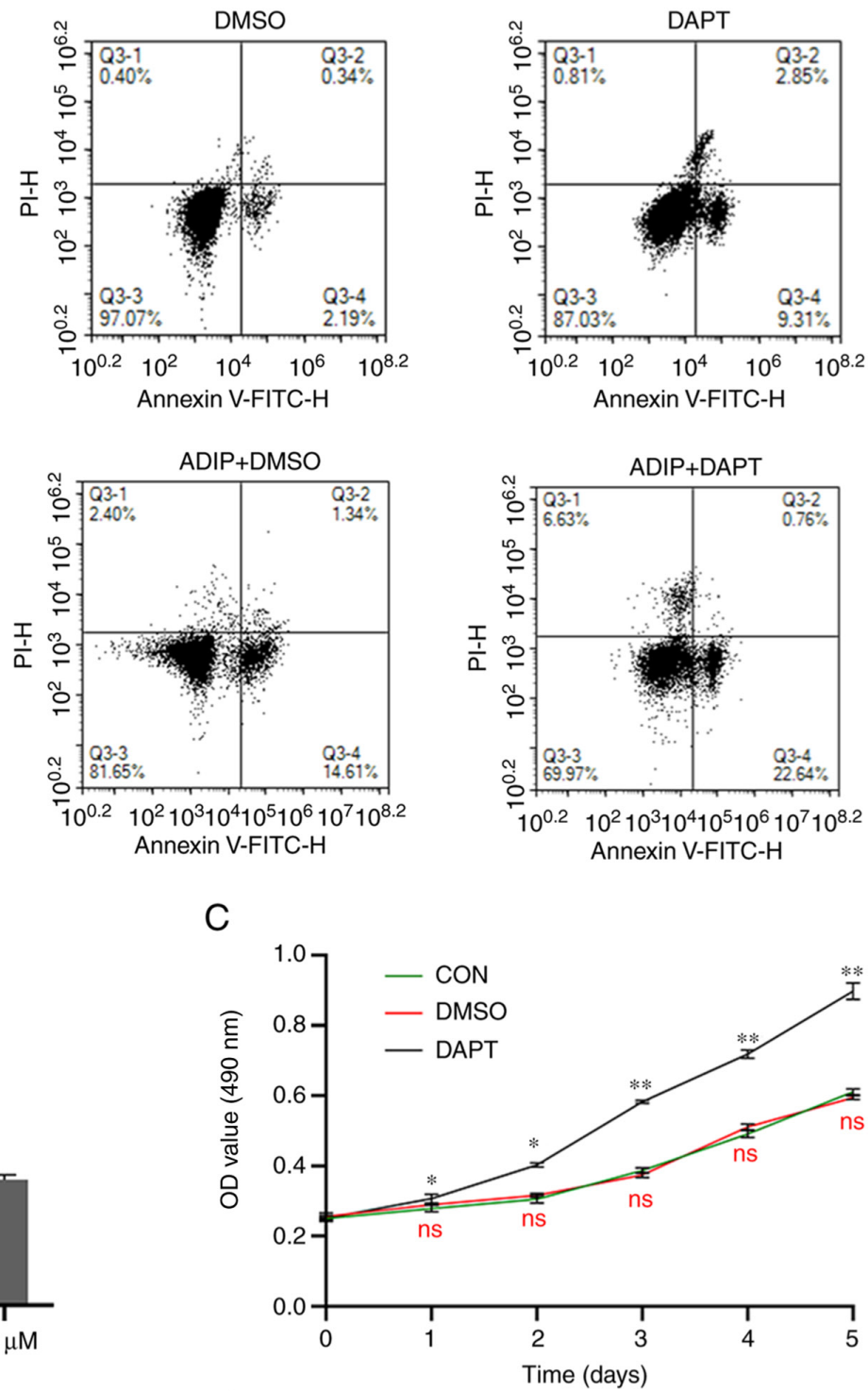

Figure 5. Apoptosis of HemSCs was promoted by DAPT exposure. (A) Proportions of apoptotic cells. (B) Proliferation of HemSCs was enhanced by DAPT in a dose-dependent manner when the concentration of DAPT was between 0 and $40 \mu \mathrm{M}$. DAPT at a concentration of $40 \mu \mathrm{M}$ induced the greatest proliferation among all groups. (C) Cell proliferation curve revealing that DAPT significantly facilitated the proliferation of HemSCs compared with the control conditions $(\mathrm{P}<0.05)$. The Cell Counting Kit-8 assay was used to determine the proliferation of HemSCs transfected with DAPT or DMSO on days 0, 1, 2, 3, 4 and 5.The proliferation of DAPT-treated HemSCs was promoted compared with the untreated group (CON, DMSO), particularly at 3-5 days. DAPT at $40 \mu \mathrm{M}$ significantly promoted the proliferation of HemSCs compared with the control group, and there was no significant difference in proliferation between the DMSO and control groups. Values are presented as the mean \pm standard deviation. $\mathrm{n}=3$. ns, $\mathrm{P}>0.05 ;{ }^{*} \mathrm{P}<0.05 ;{ }^{* *} \mathrm{P}<0.01 \mathrm{vs}$. CON (in $\mathrm{C}$ ) or as indicated. ADIP, adipogenic medium; ADIP+DAPT, adipogenic medium containing DAPT; ADIP+DMSO, adipogenic medium containing DMSO; CCK-8, Cell Counting Kit-8; CON, control; DAPT, N-[N-(3,5-difluorophenacetyl)-L-alanyl]-S-phenylglycine t-butyl ester; HemSCs, hemangioma stem cells; ns, not significant; OD, optical density.

on adipogenesis in HemSCs. Therefore, further animal-based in vivo studies are required to confirm the present hypothesis that DAPT may help drive hemangioma regression via the Notch and IGF-1 signaling pathways.

In conclusion, treatment with DAPT regulated the proliferation and differentiation of HemSCs and promoted adipogenesis, which was associated with the induction of the IGF-1 signaling pathway. Comparison of adipogenic and nonadipogenic groups revealed that adipogenesis increased the apoptosis of HemSCs, and DAPT upregulated apoptosis. In addition, the DAPT-treated adipogenic group of HemSCs exhibited higher expression levels of $\mathrm{C} / \mathrm{EBP} \alpha, \mathrm{C} / \mathrm{EBP} \beta, \mathrm{PPAR} \gamma$ and adiponectin than the control group. Therefore, inhibition of the Notch signaling pathway using DAPT may contribute to apoptosis and proliferation, as well as adipogenesis in HemSCs. This may help drive the regression of IH. However, further studies are required to validate these observations and potentially help develop a treatment strategy to accelerate the regression phase of $\mathrm{IH}$.

\section{Acknowledgements}

Not applicable.

\section{Funding}

The present study was supported by the Natural Science and Technology Fund Project of the Anhui Province (grant no. $1808085 \mathrm{MH} 282$ ). 


\section{Availability of data and materials}

The datasets used and/or analyzed during the current study are available from the corresponding author on reasonable request.

\section{Authors' contributions}

DC and XH designed the experiments. XX performed the experiments and wrote the manuscript. HL, JX and YW analyzed the experimental data. DC and XH confirm the authenticity of all the raw data. All authors read and approved the final manuscript.

\section{Ethics approval and consent to participate}

The present study was approved by the Ethics Committee of The Second Hospital of Anhui Medical University (approval no. YX2020-050F1; Hefei, China). Written informed consent was obtained from the guardians of the patients.

\section{Patient consent for publication}

Not applicable.

\section{Competing interests}

The authors declare that they have no competing interests.

\section{References}

1. Wu KQ, Muratore CS, So EY, Sun C, Dubielecka PM, Reginato AM and Liang OD: M1 macrophage-induced endothelial-to-mesenchymal transition promotes infantile hemangioma regression. Am J Pathol 187: 2102-2111, 2017.

2. Darrow DH, Greene AK, Mancini AJ and Nopper AJ: Section on Dermatology, Section on Otolaryngology-Head \& Neck Surgery, and Section on Plastic Surgery: Diagnosis and management of infantile hemangioma: Executive summary. Pediatrics 136: 786-791, 2015.

3. Bischoff J: Progenitor cells in infantile hemangioma. J Craniofac Surg 20 (Suppl 1): S695-S697, 2009.

4. Wong A, Hardy KL, Kitajewski AM, Shawber CJ, Kitajewski JK and $\mathrm{Wu} \mathrm{JK}$ : Propranolol accelerates adipogenesis in hemangioma stem cells and causes apoptosis of hemangioma endothelial cells Plast Reconstr Surg 130: 1012-1021, 2012.

5. Ji Y, Chen S, Li K, Li L, Xu C and Xiang B: Signaling pathways in the development of infantile hemangioma. J Hematol Oncol 7: 13, 2014.

6. Shen W, Huang J and Wang Y: Biological significance of NOTCH signaling strength. Front Cell Dev Biol 9: 652273, 2021

7. Pierscianek D, Wolf S, Keyvani K, El Hindy N, Stein KP, Sandalcioglu IE, Sure U, Mueller O and Zhu Y: Study of angiogenic signaling pathways in hemangioblastoma. Neuropathology 37: 3-11, 2017.

8. Baselga Torres E, Bernabéu Wittel J, van Esso Arbolave DL, Febrer Bosch MI, Carrasco Sanz Á, de Lucas Laguna R, Del Pozo Losada J, Hernández Martín Á, Jiménez Montañés L, López Gutiérrez JC, et al: Spanish consensus on infantile haemangioma. An Pediatr (Barc) 85: 256-265, 2016 (In Spanish).

9. Calicchio ML, Collins T and Kozakewich HP: Identification of signaling systems in proliferating and involuting phase infantile hemangiomas by genome-wide transcriptional profiling. Am J Pathol 174: 1638-1649, 2009.

10. Wu JK and Kitajewski JK: A potential role for notch signaling in the pathogenesis and regulation of hemangiomas. J Craniofac Surg 20 (Suppl 1): S698-S702, 2009.

11. Wu J, Adepoju O, De Silva D, Baribault K, Boscolo E, Bischoff J and Kitajewski J: A switch in Notch gene expression parallels stem cell to endothelial transition in infantile hemangioma. Angiogenesis 13: 15-23, 2010.
12. Gama-Norton L, Ferrando E, Ruiz-Herguido C, Liu Z, Guiu J, Islam AB, Lee SU, Yan M, Guidos CJ, López-Bigas N, et al: Notch signal strength controls cell fate in the haemogenic endothelium. Nat Comm 6: 8510, 2015.

13. Zhang P, Yan X, Chen Y, Yang Z and Han H: Notch signaling in blood vessels: From morphogenesis to homeostasis. Sci China Life Sci 57: 774-80, 2014.

14. Kopan R and Ilagan MX: The canonical Notch signaling pathway: Unfolding the activation mechanism. Cell 137: 216-233, 2009.

15. Grant ZL and Coultas L: Growth factor signaling pathways in vascular development and disease. Growth Factors 37: 53-67, 2019.

16. Mailhos C, Modlich U, Lewis J, Harris A, Bicknell R and Ish-Horowitz D: Delta4, an endothelial specific notch ligand expressed at sites of physiological and tumor angiogenesis. Differentiation 69: 135-144, 2001.

17. Leslie JD, Ariza-McNaughton L, Bermange AL, McAdow R, Johnson SL and Lewis J: Endothelial signaling by the Notch ligand Delta-like 4 restricts angiogenesis. Development 134: 839-844, 2007.

18. Goruganthu MUL, Shanker A, Dikov MM and Carbone DP: Specific targeting of Notch ligand-receptor interactions to modulate immune responses: A review of clinical and preclinical findings. Front Immunol 11: 1958, 2020.

19. Zhang H, Wei T, Johnson A, Sun R, Richter G and Strub GM: $\mathrm{NOTCH}$ pathway activation in infantile hemangiomas. J Vasc Surg Venous Lymphat Disord 9: 489-496, 2021.

20. Song BQ, Chi Y, Li X, Du WJ, Han ZB, Tian JJ, Li JJ, Chen F, Wu HH, Han LX, et al: Inhibition of Notch signaling promotes the adipogenic differentiation of mesenchymal stem cells through autophagy activation and PTEN-PI3K/AKT/mTOR pathway. Cell Physiol Biochem 36: 1991-2002, 2015.

21. Sandel DA, Liu M, Ogbonnaya N and Newman JJ: Notch3 is involved in adipogenesis of human adipose-derived stromal/stem cells. Biochemie 150: 31-36, 2018.

22. Chartoumpekis DV, Palliyaguru DL, Wakabayashi N, Khoo NK, Schoiswohl G, O'Doherty RM and Kensler TW: Notch intracellular domain overexpression in adipocytes confers lipodystrophy in mice. Mol Metab 4: 543-550, 2015.

23. Nandagopal N, Santat LA and Elowitz MB: Cis-activation in the Notch signaling pathway. Elife 8: e37880, 2019.

24. van Tetering G and Vooijs M: Proteolytic cleavage of Notch: 'HIT and RUN'. Curr Mol Med 11: 255-269, 2011.

25. Sprinzak D and Blacklow SC: Biophysics of Notch signaling. Annu Rev Biophys 50: 157-189, 2021.

26. Dong Z, Huo J, Liang A, Chen J, Chen G and Liu D: Gamma-Secretase Inhibitor (DAPT), a potential therapeutic target drug, caused neurotoxicity in planarian regeneration by inhibiting Notch signaling pathway. Sci Total Environ 781: 146735, 2021.

27. Menapace D, Mitkov M, Towbin R and Hogeling M: The changing face of complicated infantile hemangioma treatment. Pediatr Radiol 46: 1494-1506, 2016.

28. Chen ZY, Wang QN, Zhu YH, Zhou LY, Xu T, He ZY and Yang Y: Progress in the treatment of infantile hemangioma. Ann Transl Med 7: 692, 2019.

29. Dai G, Deng S, Guo W, Yu L, Yang J, Zhou S and Gao T: Notch pathway inhibition using DAPT, a $\gamma$-secretase inhibitor (GSI), enhances the antitumor effect of cisplatin in resistant osteosarcoma. Mol Carcinog 58: 3-18, 2019.

30. Hans CP, Sharma N, Dev R, Blain JM, Tonniges J and Agarwal G: DAPT, a potent Notch inhibitor regresses actively growing abdominal aortic aneurysm via divergent pathways. Clin Sci (Lond) 134: 1555-1572, 2020

31. Kangsamaksin T, Murtomaki A, Kofler NM, Cuervo H, Chaudhri RA, Tattersall IW, Rosenstiel PE, Shawber CJ and Kitajewski J: NOTCH decoys that selectively block DLL/NOTCH or JAG/NOTCH disrupt angiogenesis by unique mechanisms to inhibit tumor growth. Cancer Discov 5: 182-197, 2015.

32. Kerr G, Sheldon H, Chaikuad A, Alfano I, von Delft F, Bullock AN and Harris AL: A small molecule targeting ALK1 prevents Notch cooperativity and inhibits functional angiogenesis. Angiogenesis 18: 209-217, 2015.

33. Patrad E, Niapour A, Farassati F and Amani M: Combination treatment of all-trans retinoic acid (ATRA) and $\gamma$-secretase inhibitor (DAPT) cause growth inhibition and apoptosis induction in the human gastric cancer cell line. Cytotechnology 70: 865-877, 2018.

34. Liu F, Chu HX, Han JS, Sun X, Chen J, Qiu XL,Zheng XH, Jia B and Zhao JJ: Inhibitory effect of the Notch pathway-inhibitor DAPT on invasion and metastasis of tongue cancer via lncRNA-KAT14 regulation. Eur Rev Med Pharmacol Sci 24: 189-199, 2020. 
35. van der Vleuten CJM and Raphael MF: Infantile haemangioma; refer and treat on time. Ned Tijdschr Geneeskd 163: D3700, 2019 (In Dutch).

36. Wu Y, Li H, Xie J, Wang F, Cao D and Lou Y: MiR-139-5p affects cell proliferation, migration and adipogenesis by targeting insulin-like growth factor 1 receptor in hemangioma stem cells. Int J Mol Med 45: 569-577, 2020.

37. Picard A, Boscolo E, Khan ZA, Bartch TC, Mulliken JB, Vazquez MP and Bischoff J: IGF-2 and FLT-1/VEGF-R1 mRNA levels reveal distinctions and similarities between congenital and common infantile hemangioma. Pediatr Res 63: 263-267, 2008.

38. Livak KJ and Schmittgen TD: Analysis of relative gene expression data using real-time quantitative PCR and the 2(-Delta Delta C(T)) method. Methods 25: 402-408, 2001.

39. Zhang K, Wang F, Huang J, Lou Y, Xie J, Li H, Cao D and Huang X: Insulin-like growth factor 2 promotes the adipogenesis of hemangioma-derived stem cells. Exp Ther Med 17: 1663-1669, 2019.

40. Li L, Tang P, Li S, Qin X, Yang H, Wu C and Liu Y: Notch signaling pathway networks in cancer metastasis: A new target for cancer therapy. Med Oncol 34: 180, 2017.

41. Ba K, Yang X, Wu L, Wei X, Fu N, Fu Y, Cai X, Yao Y, Ge Y and Lin Y: Jagged-1-mediated activation of notch signaling induces adipogenesis of adipose-derived stem cells. Cell Prolif 45: 538-544, 2012

42. Boucher JM, Ryzhova L, Harrington A, Davis-Knowlton J, Turner JE, Cooper E, Maridas D, Ryzhov S, Rosen CJ, Vary CPH and Liaw L: Pathological conversion of mouse perivascular adipose tissue by notch activation. Arterioscler Thromb Vasc Biol 40: 2227-2243, 2020

43. Yin $\mathrm{X}$, Wei H, Wu S, Wang Z, Liu B, Guo L, Bi H and Guo D: DAPT reverses the Th17/Treg imbalance in experimental autoimmune uveitis in vitro via inhibiting Notch signaling pathway. Int Immunopharmacol 79: 106107, 2020.

44. Sun W, Li J, Li Y, Zheng J, Zhang X, Huang X and Li S: Gamma-secretase inhibitor, DAPT, prevents the development of retinopathy of prematurity in a rat model by regulating the Delta-Like Ligand 4/Notch Homolog-1 (DLL4/Notch-1) pathway. Med Sci Monit 25: 492-499, 2019.

45. Svedružić ŽM, Popović K and Šendula-Jengić V: Modulators of $\gamma$-secretase activity can facilitate the toxic side-effects and pathogenesis of Alzheimer's disease. PLoS One 8: e50759, 2013.

46. Wang M, Ma X, Wang J, Wang L and Wang Y: Pretreatment with the $\gamma$-secretase inhibitor DAPT sensitizes drug-resistant ovarian cancer cells to cisplatin by downregulation of Notch signaling. Int J Oncol 44: 1401-1409, 2014.

47. Su F, Zhu S, Ruan J, Muftuoglu Y, Zhang L and Yuan Q: Combination therapy of RY10-4 with the $\gamma$-secretase inhibitor DAPT shows promise in treating HER2-amplified breast cancer. Oncotarget 7: 4142-4154, 2016.

48. Mori M,Miyamoto T, YakushijiH,Ohno S, Miyake Y,SakaguchiT, Hattori M, Hongo A, Nakaizumi A, Ueda M and Ohno E: Effects of $\mathrm{N}$-[N-(3,5-difluorophenacetyl-L-alanyl)]-S-phenylglycine t-butyl ester (DAPT) on cell proliferation and apoptosis in Ishikawa endometrial cancer cells. Hum Cell 25: 9-15, 2012

49. Li JY, Li RJ and Wang HD: $\gamma$-secretase inhibitor DAPT sensitizes t-AUCB-induced apoptosis of human glioblastoma cells in vitro via blocking the p38 MAPK/MAPKAPK2/Hsp27 pathway. Acta Pharmacol Sin 35: 825-831, 2014.

50. Hubmann R, Sieghart W, Schnabl S, Araghi M, Hilgarth M, Reiter M, Demirtas D, Valent P, Zielinski C, Jäger U and Shehata M: Gliotoxin targets nuclear NOTCH2 in human solid tumor derived cell lines in vitro and inhibits melanoma growth in xenograft mouse model. Front Pharmacol 8: 319, 2017.

51. Rodríguez-Cano MM, González-Gómez MJ, Sánchez-Solana B, Monsalve EM, Díaz-Guerra MM, Laborda J, Nueda ML and Baladrón V: NOTCH receptors and DLK proteins enhance brown adipogenesis in mesenchymal C3H10T1/2 cells. Cells 9: 2032, 2020

52. Marey HM, Elmazar HF, Mandour SS and Khairy HA: Combined oral and topical beta blockers for the treatment of early proliferative superficial periocular infantile capillary hemangioma. J Pediatr Ophthalmol Strabismus 55: 37-42, 2018.
53. Reshi L, Wang HV, Hui CF, Su YC and Hong JR: Anti-apoptotic genes $\mathrm{Bcl}-2$ and $\mathrm{Bcl}-\mathrm{xL}$ overexpression can block iridovirus serine/threonine kinase-induced Bax/mitochondria-mediated cell death in GF-1 cells. Fish Shellfish Immunol 61: 120-129, 2017.

54. Reshi L, Wu HC, Wu JL, Wang HV and Hong JR: GSIV serine/threenine kinase can induee apeptetie cell death via p53 and pro-apoptotic gene Bax upregulation in fish cells. Apoptosis 21: 443-458, 2016.

55. Ma SB, Nguyen TN, Tan I, Ninnis R, Iyer S, Stroud DA, Menard M, Kluck RM, Ryan MT and Dewson G: Bax targets mitochondria by distinct mechanisms before or during apoptotic cell death: A requirement for VDAC2 or Bak for efficient Bax apoptotic function. Cell Death Differ 21: 1925-1935, 2014

56. Wang F, Long J, Li L, Zhao ZB, Wei F, Yao Y, Qiu WJ, Wu ZX, Luo QQ, Liu W, et al: Mutations in the notch signalling pathway are associated with enhanced anti-tumour immunity in colorectal cancer. J Cell Mol Med 24: 12176-12187, 2020.

57. Bridges E, Sheldon H, Kleibeuker E, Ramberger E, Zois C, Barnard A, Harjes U, Li JL, Masiero M, MacLaren R and Harris A: RHOQ is induced by DLL4 and regulates angiogenesis by determining the intracellular route of the Notch intracellular domain. Angiogenesis 23: 493-513, 2020.

58. Xue P, Hou Y, Zuo Z, Wang Z, Ren S, Dong J, Fu J, Wang H, Andersen ME, Zhang Q, et al: Long isoforms of NRF1 negatively regulate adipogenesis via suppression of PPAR $\gamma$ expression. Redox Biol 30: 101414, 2020.

59. Musri MM and Párrizas M: Epigenetic regulation of adipogenesis. Curr Opin Clin Nutr Metab Care 15: 342-349, 2012.

60. Lee JE, Schmidt H, Lai B and Ge K: Transcriptional and epigenomic regulation of adipogenesis. Mol Cell Biol 39: e00601-e00618, 2019.

61. Xu Z, Meng SH, Bai JG, Sun C, Zhao LL, Tang RF, Yin ZL, Yin ZL, Ji JW, Yang W and Ma GJ: C/EBP $\alpha$ Regulates FOXC1 to modulate tumor growth by interacting with PPAR $\gamma$ in hepatocellular carcinoma. Curr Cancer Drug Targets 20: 59-66, 2020.

62. Laviola L, Natalicchio A and Giorgino F: The IGF-I signaling pathway. Curr Pharm Des 13: 663-669, 2007.

63. Weroha SJ and Haluska P: The insulin-like growth factor system in cancer. Endocrinol Metab Clin North Am 41: 335-350, vi, 2012.

64. Zaher H, Rasheed H, El-Komy MM, Hegazy RA, Gawdat HI, Abdel Halim DM, Abdel Hay RM, Hegazy RA and Mohy AM: Propranolol versus captopril in the treatment of infantile hemangioma (IH): A randomized controlled trial. J Am Acad Dermatol 74: 499-505, 2016.

65. Ferreira Mendes JM, de Faro Valverde L, Torres Andion Vidal M, Paredes BD, Coelho P, Allahdadi KJ, Coletta RD, Souza BSF and Rocha CAG: Effects of IGF-1 on proliferation, angiogenesis, tumor stem cell populations and activation of AKT and hedgehog pathways in oral squamous cell carcinoma. Int J Mol Sci 21: 6487,2020

66. Wang F, Li H, Lou Y, Xie J, Cao D and Huang X: Insulinlike growth factor I promotes adipogenesis in hemangioma stem cells from infantile hemangiomas. Mol Med Rep 19: 2825-2830, 2019.

67. Fuentes-Baile M, Ventero MP, Encinar JA, García-Morales P, Poveda-Deltell M, Pérez-Valenciano E, Barberá VM, Gallego-Plazas J, Rodríguez-Lescure Á, Martín-Nieto J and Saceda M: Differential effects of IGF-1R small molecule tyrosine kinase inhibitors BMS-754807 and OSI-906 on human cancer cell lines. Cancers (Basel) 12: 3717, 2020.

This work is licensed under a Creative Commons Attribution-NonCommercial-NoDerivatives 4.0 International (CC BY-NC-ND 4.0) License. 